Ohlson, M. A., Brewer, W. D., Cederquist, D. C., Jackson, L., Brown, E. G. \& Roberts, P. H. (1948). 7. Amer, diet. Ass. 24, 744.

Perlmutter, M. \& Riggs, D. S. (1949). F. clin. Endocr. 9, $43^{\circ}$.

Schlossmann, A. \& Murschhauser, H. (I914). Biochem. Z. 58, 483 .

Smuts, D. B. (1935). F. Nutr. 9, 403.

Strangeways, W. M. B. (1954). To be published.

Talbot, F. B. (1925). Physiol. Rev. 5, 477.

Terroine, E. F., Boy, G., Champagne, N. \& Mourot, G. (1933). Bull. Soc. Chim. biol., Paris, I5, 42.

Voit, C. (1878). Z. Biol. 14, sect. 12, 57 .

Widdowson, E. M. (ฯ.936). F. Hyg., Camb., 36, 269.

Widdowson, E. M. \& McCance, R. A. (1936). F. Hyg., Camb., 36, 293.

Widdowson, E. M. \& Spray, C. M. (1951). Arch. Dis. Childh. 26, 205.

\title{
Studies of the Site of Conversion of $\beta$-Carotene Injected Intravenously into Rats
}

\author{
BY J. G. BIERI AND CLIFFORD J. POLLARD \\ Department of Biochemistry and Nutrition, University of Texas Medical Branch, \\ Galveston, Texas
}

(Received 26 fune 1953)

It has been known since the work of Drummond, Gilding \& Macwalter (I934) and Drummond \& Macwalter (r935) that when colloidal carotene is introduced directly into the circulation of animals the liver rapidly removes the pigment much as it does many other colloidal substances. Such carotene, as well as that deposited in the liver when colloidal carotene is given by other parenteral routes, is essentially not available to the animal as a source of vitamin $A$ and may still be found in the liver after the animal has died from an apparent deficiency of the vitamin (Lease, Lease, Steenbock \& Baumann, 194.2; Sexton, Mehl \& Deuel, r946). With the discovery by Tomarelli, Charney \& Bernhart (1946) that parenteral carotene can serve as an effective source of vitamin A provided it is solubilized in water with a surface-active agent, it became apparent that the parenteral utilization of the provitamin was primarily a question of its physical state in the aqueous medium administered.

Recently, Eaton, Matterson, Decker, Helmboldt \& Jungherr (r95I) injected an aqueous suspension of carotene intravenously into vitamin A-depleted calves and observed slight increases in plasma vitamin A levels. No increased storage of vitamin $A$ in the liver, however, was found. Kowalewski, Henrotin \& van Geertruyden (I95 I) have reported that colloidal carotene injected intravenously into dogs gave rise to considerable increases in vitamin $\mathrm{A}$ in the serum and liver within $2 \mathrm{~h}$.

In a previous study of the availability of solubilized carotene injected intramuscularly into vitamin A-depleted rats (Bieri \& Schultze, I95 I $b$ ), only small amounts of vitamin A were found in the serum and kidneys, and none was present in the liver. This indicated a rather inefficient utilization of the parenteral carotene, and subsequent investigation 
(Bieri \& Sandman, 195I) showed that for maximum growth of young rats approximately five times as much carotene was required intramuscularly as orally.

Since it is well established that the small intestine is the site of conversion of carotene administered orally to rats (Glover, Goodwin \& Morton, 1947; Mattson, Mehl \& Deuel, I947; Thompson, Ganguly \& Kon, 1947), it might be assumed that injected carotene must first be transported to the intestine via the circulation or the bile and there be transformed into vitamin A. In this paper it is shown that, under some conditions, carotene administered intravenously is as efficiently utilized as when given orally and that the injected carotene is converted into vitamin A primarily in tissues other than the small intestine.

\section{EXPERIMENTAL}

Animals and diets. For the growth studies Holtzman weanling rats when received were fed on the U.S.P. XIII vitamin A-assay ration for 10-13 days and then on a purified vitamin A-free diet (Bieri \& Sandman, I95I) for the remainder of the experiment. Male rats were used in all studies except one, noted below. The consumption of both diets was restricted slightly during the depletion period to achieve greater uniformity in body-weight and in the time required for depletion. Signs of vitamin A deficiency appeared in male animals rather uniformly in $15^{-18}$ days when bodyweights were $95^{-1} I_{5} \mathrm{~g}$; females required a few days longer. Groups of six to eight animals were selected, similar in weight. After administration of the carotene supplement, the food was offered unrestricted. The curative experiments were begun when the animals had manifested signs of vitamin A deficiency for $1-3$ days and the preventive experiments 2-4 days before signs would be expected to appear. For the surgical studies, rats weighing $100-140 \mathrm{~g}$ and having manifested signs of vitamin $\mathrm{A}$ deficiency for $3-7$ days were used.

Carotene supplements. The supplements of carotene in $0.2 \mathrm{ml}$. solution were administered orally by stomach tube (blunt needle) or intravenously via the tail vein while the animal was under light ether anaesthesia. Crystalline all-trans- $\beta$-carotene, used in all experiments, was obtained commercially or prepared chromatographically from a mixture of $\alpha$ - and $\beta$-carotenes. The aqueous solutions were prepared as described previously (Bieri, I95I) with the concentration of Tween 40 (polyoxyethylenesorbitan monopalmitate) ranging from $\mathrm{I}$ to $20 \%$ in different experiments. In preparing solutions containing more than $200 \mu \mathrm{g}$ carotene $/ \mathrm{ml}$. it was found necessary to heat the Tween solution to about $80^{\circ}$ while adding water, in order to keep the carotene in solution. Such heating for I min, or less, did not produce significant isomerization of the carotene as determined spectrophotometrically. When DL- $\alpha-$ tocopherol was incorporated in the solutions, it was first dissolved in the Tween. If the carotene solutions were not perfectly clear they were rejected, since it was found (unpublished observation) that even when solutions are only slightly turbid the carotene is more rapidly removed from the blood by the tissues.

Analytical methods. Vitamin A was determined with antimony trichloride after separation from carotene. With serum, it was frequently found that the usual $20 \mathrm{~min}$ saponification with I $\mathrm{N}$-alcoholic $\mathrm{KOH}$ at $60^{\circ}$ was insufficient to release the carotene 
from its complex with the Tween. Consequently the pigment remained in the aqueous phase while the vitamin A was removed by the solvent (hexane). Continued saponification for an additional $20 \mathrm{~min}$ then permitted extraction of the carotene. With the livers and kidneys, the extracts of the unsaponifiable material, after washing and drying, were chromatographed on alumina and the carotene was permitted to pass through the column. The vitamin A was then eluted with $20 \%$ acetone in hexane and transferred to chloroform, and the antimony-trichloride determination was performed with the Coleman Junior Spectrophotometer. Carotene was read at $45^{\circ} \mathrm{m} \mu$. Whenever it was questionable whether or not the small amount of yellow pigment sometimes obtained from tissues was carotene, its identity was checked spectrophotometrically. For the serum-vitamin A determinations, a semi-micro procedure using $10 \mathrm{~mm}$ cuvettes was employed, which permits a satisfactory reading with as little as $0.25 \mu \mathrm{g}$ vitamin A. A distinct blue, fading colour was noted in all acceptable determinations with antimony trichloride. In some instances the serum analyses were made by the microspectrophotometric method (Bessey, Lowry, Brock \& Lopez, 1946; Bieri \& Schultze, $195 \mathrm{I} a$ ). Additional verification that vitamin A was the substance being determined was provided by the characteristic vitamin $A$ absorption curve of the unsaponifiable extracts from representative serums and livers and by the absorption maxima at 555 and $620 \mathrm{~m} \mu$ of the reaction mixture of similar liver extracts with glycerol dichlorhydrin (Sobel \& Werbin, 1945) and antimony trichloride, respectively.

Surgical procedures. Ether anaesthesia was used in all operations. The enterectomy was performed by ligating the mesenteric vessels in bunches, tying off the intestine at the stomach and caecum, and stripping out the gut. The large intestine was left intact. A drainage cannula from the stomach, through the incision to the outside, permitted removal of the gastric secretion. Nephrectomy was performed by a standard procedure (Farris \& Griffith, 1949). In the hepatectomy, the median and left lobes were excised with a single ligature. From 60 to $75 \%$ of the organ was removed in the various experiments. In rats in which the flow of bile to the intestine was interrupted, the bile duct was doubly ligated and severed between the ligatures.

Immediately after the operations, while the animals were still anaesthetized, $0.2 \mathrm{ml}$. of carotene solution was injected into the tail vein. After 4-8 h the animals were either decapitated or bled to death from the descending aorta. The short time interval was necessary, since the severe state of shock of the operated animals, particularly after enterectomy and hepatectomy, limited their survival to $4^{-10} \mathrm{~h}$.

RESULTS

\section{Growth response to intravenous carotene}

Preventive studies. In the first preventive experiments, the growth response to carotene without tocopherol was compared orally and intravenously. When a single dose of $50 \mu \mathrm{g}$ was given to each of the animals in two groups of rats, average weight $96 \cdot 4 \pm \mathrm{I} \cdot 4 \mathrm{~g}$, the injected group gained at a slightly better rate than that given carotene by mouth. Both groups, however, began to lose weight after the 2oth day, when the injected rats had gained an average of $96.7 \mathrm{~g}$ compared with $93.2 \mathrm{~g}$ for the orally treated rats. 
The response to a small supplement of carotene, $4.0 \mu \mathrm{g}$, was tested in two groups of seven animals, average weight $109 \cdot 6 \pm 0 \cdot 1 \mathrm{~g}$ (Fig. I). The response of the injected group was considerably better than that of the other, the average weight gains for the 8-day period, when growth ceased, being $44^{\circ} 4$ and $36.3 \mathrm{~g}$, respectively. A negativecontrol group, receiving no supplement, developed deficiency symptoms within 4 days, when their weights dropped sharply. In a repetition of this experiment $(4 \cdot \mathrm{I} \mu \mathrm{g}$

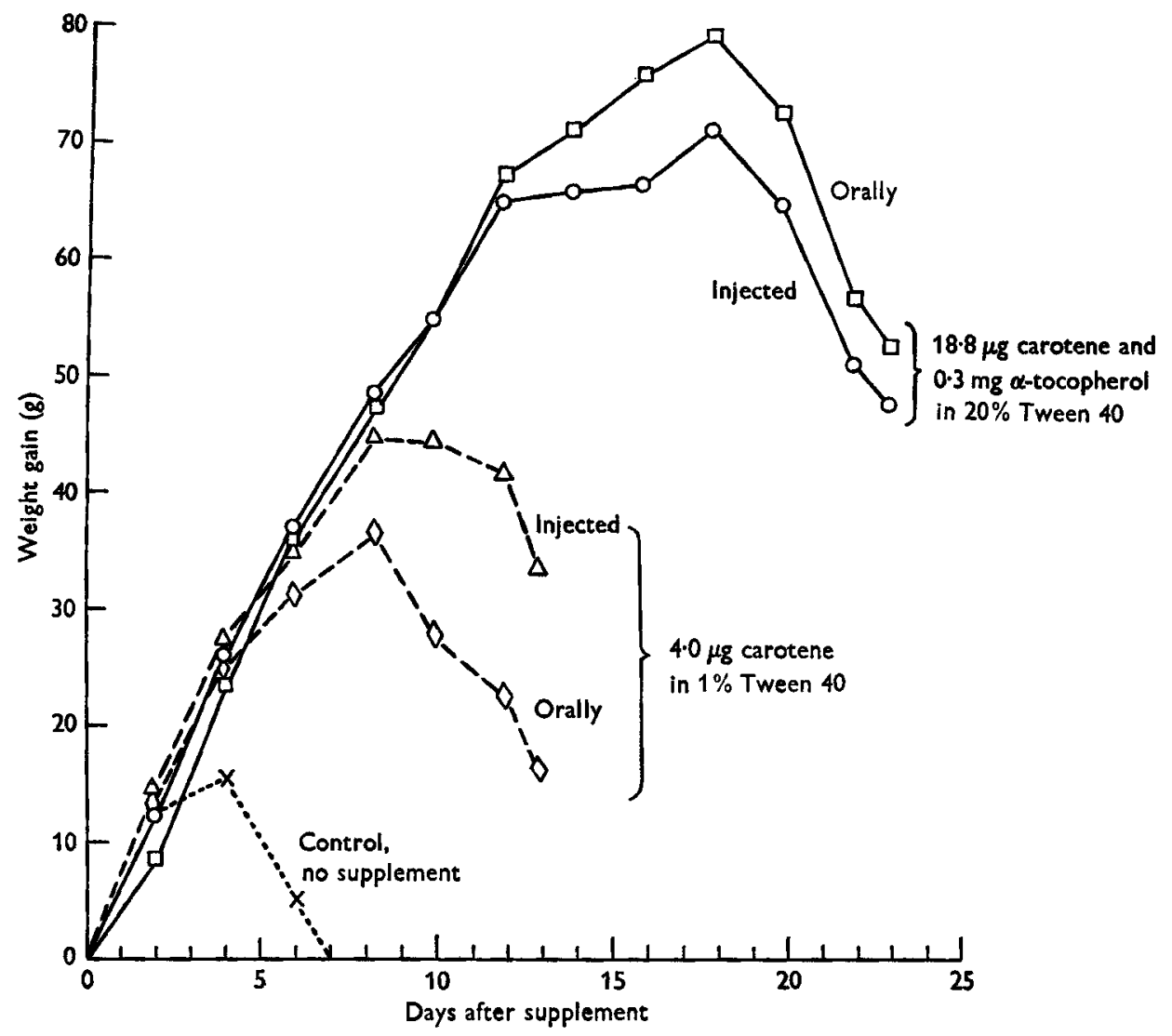

Fig. I. Growth response of vitamin A-depleted rats, not showing signs of deficiency, after administration of a single dose of carotene in aqueous dispersion, with or without tocopherol, orally or intravenously. Average values for groups of seven rats.

carotene) on two groups of seven rats of average weight $98 \cdot 0 \pm 0.7 \mathrm{~g}$, the injected animals in 9 days gained $32.3 \mathrm{~g}$, while those given carotene by mouth gained only $2 \mathrm{r} \cdot 8 \mathrm{~g}$ in 7 days, before growth ceased. At the end of ${ }_{5} 5$ days, six injected and only two orally treated rats were still alive.

The effect of $\alpha$-tocopherol on the utilization of carotene administered intravenously was studied with two groups of seven rats, average weight $110.2 \pm 0.2 \mathrm{~g}$. When a supplement of $18.8 \mu \mathrm{g}$ carotene containing $0.3 \mathrm{mg} \alpha$-tocopherol was administered orally or intravenously, the two groups continued to gain similarly for 12 days, when the injected animals began to level off (Fig. I). Both groups reached their maximum 
gains on the 18 th day, when the orally treated animals had gained $79 \cdot 2 \mathrm{~g}$ compared with $70.9 \mathrm{~g}$ for the injected animals. In a repeat experiment at the same dosage, with six rats per group, almost identical results were obtained, i.e. the oral route was more effective than the intravenous route.

Curative studies. When the effect of tocopherol on the biological activity of intravenously administered carotene was investigated in animals showing signs of vitamin A deficiency of 2-3 days' duration, a very poor response was obtained. On studying this further it was found that when animals were deficient low doses of

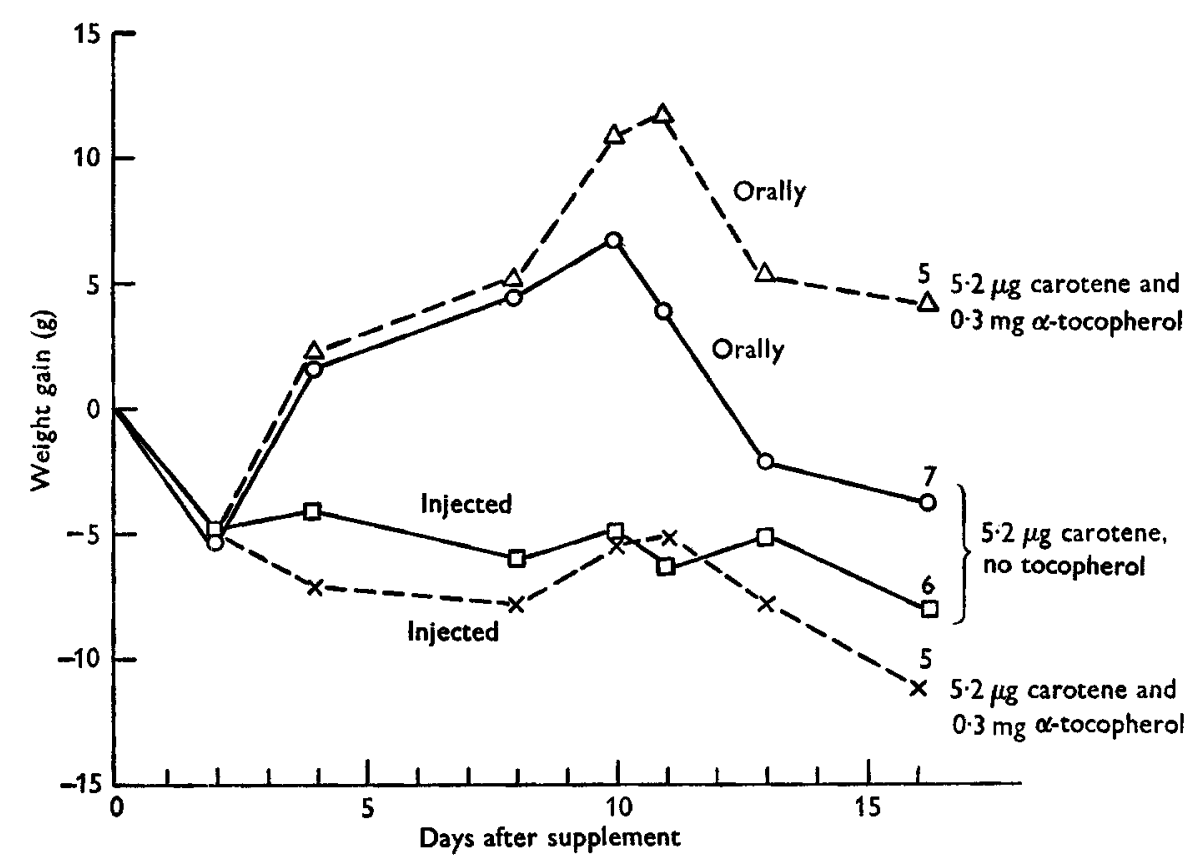

Fig. 2. Growth response of vitamin A-deficient female rats to a single small supplement of carotene in aqueous dispersion with $2.6 \%$ Tween 40 , with or without tocopherol, administered orally or intravenously. Numbers at ends of curves indicate number of survivors. Average values for groups initially of seven rats.

carotene, with or without tocopherol, were considerably less active intravenously than orally. In Fig. 2 are the growth curves of four groups of female rats, initial average weight $106 \cdot 2 \pm \mathrm{r} \cdot 7 \mathrm{~g}$, to which were administered orally or intravenously $5.2 \mu \mathrm{g}$ carotene with or without tocopherol. All groups continued to lose weight for 2 days after the supplement. The orally treated animals then responded to the carotene, with the group receiving tocopherol outgaining those without the anti-oxidant, as anticipated (Harris, Kaley \& Hickman, I944). The injected groups, in contrast, did not respond significantly, but were able to maintain weight for 10-1 3 days, the rats not receiving tocopherol showing a better initial performance. The number of deaths in the various groups was similar at 16 days. These results are similar to those obtained in a preliminary study with male rats, so that sex is not a factor in the decreased utilization of intravenous carotene under curative conditions. When a curative experiment was 
carried out by giving to two groups of eight rats (average weight $110 \pm 0.2 \mathrm{~g}$ ), which had lost weight for $1-2$ days, $18.8 \mu \mathrm{g}$ carotene with $0.3 \mathrm{mg} \alpha$-tocopherol, the injected group gained the same as that orally treated ( $53^{\circ} 9$ and $55^{\circ} 6 \mathrm{~g}$, respectively), but the former reached a slightly lower maximum 2 days earlier.

\section{Distribution of vitamin $A$ and carotene in tissues of rats after carotene injection}

In order to determine the fate of solubilized aqueous carotene introduced into the circulation, a series of experiments was carried out with vitamin A-deficient rats weighing $100-120 \mathrm{~g}$. The distribution of carotene in the body $4 \mathrm{~h}$ after injecting $69 \mu \mathrm{g}$ of the compound is given in Table $\mathrm{I}$. About one-third of the supplement appeared in

\section{Table I. Distribution of carotene in the body of rats $4 h$ after injecting intravenously $69 \mu \mathrm{g}$ carotene in aqueous dispersion}

(Average values, with ranges, for five rats, in $\mu \mathrm{g}$ )

$\begin{array}{lc}\text { Carcass } & \text { I } 4.0(12 \cdot 2-15.9) \\ \text { Liver } & \text { I9.2 }(14 \cdot 2-23.0) \\ \text { Kidneys } & 0.9(0.3-2.0) \\ \text { Lungs } & 2.2(x \cdot 2-3.4) \\ \text { Heart } & 0.4(0.3-0.5)\end{array}$

* Includes carotene in approximately $2 \cdot 0 \mathrm{ml}$. blood collected.

$\begin{array}{lc}\text { Spleen } & 2 \cdot 0(0 \cdot 5-4 \cdot 3) \\ \text { Small intestine } & 2 \cdot 4(0 \cdot 7-4 \cdot 5) \\ \text { Serum }(\mu \mathrm{g} / \mathrm{I} 00 \mathrm{ml} .) & 331 \cdot 0(2.16-56 \mathrm{I}) \\ \text { Total carotene } & 47 \cdot 4(43 \cdot 8-50 \cdot 4) * \\ \text { Carotene recovered } & 67 \cdot 2(63 \cdot 5-73 \cdot \mathrm{I})\end{array}$

$(\%)$

the liver and about one-fourth was found in the carcass (excluding the head). Small amounts $(\mathrm{I}-5 \mu \mathrm{g})$ were found in the lungs, spleen and small intestine, and only traces were detected in the kidneys and heart. No carotene was found in the brain, eyes, thyroid glands or testes. A considerable portion of the carotene, estimated at about $20 \mu \mathrm{g}$ on the assumption that $6 \%$ of the body-weight is blood, was still in the blood. An average of $67 \cdot 2 \%$ of the injected carotene was recovered.

The possibility that the injected carotene might be eliminated from the body in the urine or faeces was tested with four vitamin A-deficient rats weighing $140-175 \mathrm{~g}$. After injecting $96 \mu$ g solubilized carotene intravenously into each rat, the excreta were collected for a 4-day period. No carotene was found in either the urine or faeces.

An experiment was carried out in order to determine the distribution of vitamin A and carotene in liver, kidneys and serum at varying time intervals after administering carotene intravenously. Deficient rats weighing 75-100 g were injected with $100 \mu \mathrm{g}$ carotene and killed at intervals, and the organs were analysed. The results are given in Table 2. Carotene in the serum decreased slowly for $18 \mathrm{~h}$ and had completely disappeared at the end of $48 \mathrm{~h}$. The bulk of the carotene was rapidly deposited in the liver and a constant amount maintained for $6-\mathrm{I} 8 \mathrm{~h}$. A gradual decrease then followed, until at $48 \mathrm{~h}$ half of the carotene remained and at 96 and $\mathrm{i} 68 \mathrm{~h}$ about one-third was still present. (Animals receiving similar amounts of carotene intravenously, and permitted to continue until they died from vitamin A deficiency, had from o to $4 \mu \mathrm{g}$ carotene in the liver.) Only a trace of carotene appeared in the kidneys and this disappeared after $48 \mathrm{~h}$. Small amounts of carotene, $2-5 \mu \mathrm{g}$, present in the intestine, lungs and spleen from 6 to $18 \mathrm{~h}$, slowly decreased, until at $\mathrm{I} 68 \mathrm{~h}$ no carotene was in the lungs and only traces were in the intestine and spleen (not included in Table 2). 
Table 2. Carotene and vitamin $A$ in tissues of rats at various time intervals after injecting intravenously $100 \mu \mathrm{g}$ carotene in aqueous dispersion

(Where more than one rat was used, values given are averages)

\begin{tabular}{|c|c|c|c|c|c|c|c|}
\hline \multirow[b]{2}{*}{$\begin{array}{l}\text { No. of } \\
\text { rats }\end{array}$} & \multirow[b]{2}{*}{ Time } & \multicolumn{2}{|c|}{ Serum } & \multicolumn{2}{|c|}{ Liver } & \multicolumn{2}{|c|}{ Kidneys } \\
\hline & & $\begin{array}{c}\text { Carotene } \\
(\mu \mathrm{g} / \text { roo ml. })\end{array}$ & $\begin{array}{c}\text { Vitamin A } \\
(\mu \mathrm{g} / 100 \mathrm{ml} .)\end{array}$ & $\begin{array}{c}\text { Carotene } \\
(\mu \mathrm{g})\end{array}$ & $\begin{array}{l}\text { Vitamin } A \\
(\mu \mathrm{g})\end{array}$ & $\begin{array}{c}\text { Carotene } \\
(\mu \mathrm{g})\end{array}$ & $\underset{(\mu \mathrm{g})}{\text { Vitamin }} A$ \\
\hline 2 & $5 \mathrm{~min}$ & 2130 & $I_{4} \cdot 2$ & 10.3 & 0 & $I \cdot 4$ & $\circ$ \\
\hline 2 & $6 \mathrm{~h}$ & 584 & $134^{\circ} 0$ & $35 \cdot 3$ & $2 \cdot 4$ & 0.5 & $x \cdot 7$ \\
\hline 3 & $12 \mathrm{~h}$ & 277 & $3 I 0$ & $39 \cdot 4$ & $3 \cdot 2$ & 0.5 & $2 * 4$ \\
\hline 2 & I $8 \mathrm{~h}$ & 150 & $3 I \cdot 2$ & $37 \cdot 0$ & $4 \cdot 6$ & 0.6 & $3 \cdot 4$ \\
\hline I & $48 \mathrm{~h}$ & 0 & $18 \cdot 0$ & I9. I & $1 \cdot 5$ & 0.3 & $2-7$ \\
\hline I & $96 \mathrm{~h}$ & 0 & 10.7 & $I I \cdot I$ & $I \cdot 2$ & 0 & $3 \cdot 6$ \\
\hline I & I $68 \mathrm{~h}$ & 0 & $8 \cdot I$ & 12.3 & 0 & 0 & 0.9 \\
\hline
\end{tabular}

Vitamin $\mathrm{A}$ appeared rapidly in the blood and by $6 \mathrm{~h}$ concentrations above $100 \mu \mathrm{g} /$ I00 $\mathrm{ml}$. were found. This vitamin A was quickly removed from the blood until at $12 \mathrm{~h}$ the level was only $3 \mathrm{I} \mu \mathrm{g} / 100 \mathrm{ml}$. During the next 7 days the content decreased slowly to a value of $8 \cdot 1 \mu \mathrm{g} / 100 \mathrm{ml}$. Slightly larger amounts of vitamin A were deposited in the liver than in the kidneys, the maximum amount in each tissue being present $18 \mathrm{~h}$ after injection. The liver vitamin $A$ then decreased to about one-fourth by 4 days, while the kidney vitamin A remained almost constant for this period. After 7 days, no vitamin A was found in the liver but almost $\mathbf{I} \mu \mathrm{g}$ was still in the kidneys. No vitamin A was detectable in the lungs or spleen, and less than $0.5 \mu \mathrm{g}$ was found in the small intestine at any time interval of this experiment.

It is important to mention that deficient rats in this laboratory have an 'apparent' vitamin A content in the combined livers and kidneys of less than $0.5 \mu \mathrm{g}$. Since this is the lower limit of detection in the procedure used, any values greater than $0.5 \mu \mathrm{g}$ are considered significant.

The prolonged low serum-vitamin A level observed in the above experiment was studied further in a comparison with the serum levels resulting from the administration of carotene orally. Since it had been determined in our laboratory (unpublished) that about $40-50 \%$ of oral doses of aqueous carotene are excreted in the faeces, in the following experiment twice as much carotene was given by the oral route as by the intravenous. Of five vitamin A-deficient animals (90-130 g) three were given $76 \mu \mathrm{g}$ carotene in $0.2 \mathrm{ml}$. intravenously and two $152 \mu \mathrm{g}$ in $0.4 \mathrm{ml}$. by stomach tube. At intervals tail blood was collected and the vitamin $A$ and carotene in the serum were determined by the microspectrophotometric method. The results, Table 3 , show that after I day the serum vitamin $A$ of orally treated animals was double that of the injected group, and this relationship persisted throughout the ${ }_{15}$-day period. The vitamin A in the injected group levelled off after I $\mathrm{I}$ days, and was constant at the low concentration of about $6 \mu \mathrm{g} / 100 \mathrm{ml}$. for the remaining 4 -day period. When the animals were killed on the $15^{\text {th }}$ day, an average of $2.4 \mu \mathrm{g}$ vitamin A per animal was present in the combined livers and kidneys of the orally treated group, but none was found in the same tissues from injected rats. The combined kidneys and livers of the latter 
contained an average of $15.7 \mu \mathrm{g}$ carotene per animal, the remaining viscera $4.6 \mu \mathrm{g}$ and the carcass $4.7 \mu \mathrm{g}$ carotene. No carotene was found in any tissues of the orally treated group.

Table 3. Vitamin $A$ in serum of deficient rats at intervals after administering a single dose of carotene in aqueous dispersion orally or intravenously

\begin{tabular}{|c|c|c|}
\hline \multicolumn{3}{|c|}{ (Average values with ranges) } \\
\hline $\begin{array}{c}\text { Day after } \\
\text { supplement }\end{array}$ & $\begin{array}{c}76 \cdot 4 \mu \mathrm{g} \text { carotene } \\
\text { intravenously* } \\
(\mu \mathrm{g} / \mathrm{L} \infty 0 \mathrm{ml} .)\end{array}$ & $\begin{array}{c}\text { I } 52.8 \mu \mathrm{g} \text { carotene } \\
\text { orally } \\
(\mu \mathrm{g} / \mathrm{roo} \mathrm{ml} .)\end{array}$ \\
\hline I & $36 \cdot 1(32 \cdot 2-40 \cdot 8)$ & $70.9(53.8-87.9)$ \\
\hline 4 & $20 \cdot 4(17 \cdot 2-22 \cdot 0)$ & $39 \cdot 8(33 \cdot 9-45 \cdot 6)$ \\
\hline 7 & $I 3 \cdot 9(I I \cdot 8-I 6 \cdot I)$ & $33 \cdot 8(25 \cdot 2-42 \cdot 4)$ \\
\hline I I & $6 \cdot 0(2 \cdot 1-10 \cdot 1)$ & $23 \cdot 4(18 \cdot 3-28 \cdot 4)$ \\
\hline I5 & $6 \cdot I(4 \cdot 8-8 \cdot I)$ & $13.5(12.4-14.5)$ \\
\hline
\end{tabular}

Comparison of vitamin A storage from repeated administrations of carotene orally or intravenously

In an experiment to compare the liver and kidney storage of vitamin A after repeated administrations of aqueous carotene by the two routes, deficient rats weighing 100-120 $\mathrm{g}$ were given orally or intravenously a total of $98-110 \mu \mathrm{g}$ carotene in divided doses on 4 consecutive days. Twenty-four hours after the last supplement the animals were killed and the serums, livers and kidneys analysed for vitamin $\mathrm{A}$ and carotene. From the results in Table 4 it can be seen that the rats receiving carotene intravenously stored the same amount of vitamin $A$ in their livers and kidneys as did those orally treated. The injected group had a slightly higher concentration of vitamin A in the serum. About one-fourth of the carotene administered was deposited in the livers of the injected rats, whereas only small amounts were found in the livers of those orally treated.

Table 4. Vitamin $A$ and carotene in tissues of rats after administration, orally or intravenously, of a total of 98-1 10 $\mu \mathrm{g}$ carotene in aqueous dispersion in divided doses on 4 consecutive days

(Average values with ranges)

\begin{tabular}{|c|c|c|c|c|c|}
\hline \multirow[b]{2}{*}{$\begin{array}{l}\text { No. of } \\
\text { rats }\end{array}$} & \multirow[b]{2}{*}{$\begin{array}{c}\text { Route of } \\
\text { administration }\end{array}$} & \multicolumn{3}{|c|}{ Vitamin A } & \multirow{2}{*}{$\begin{array}{c}\text { Carotene } \\
\text { Liver* } \\
(\mu \mathrm{g})\end{array}$} \\
\hline & & $\begin{array}{c}\text { Serum } \\
(\mu \mathrm{g} / 100 \mathrm{ml} .)\end{array}$ & $\begin{array}{l}\text { Kidneys } \\
\qquad(\mu \mathrm{g})\end{array}$ & $\begin{array}{c}\text { Liver } \\
(\mu \mathrm{g})\end{array}$ & \\
\hline 4 & Oral & $\begin{array}{c}54 \cdot 5 \\
(39-74)\end{array}$ & $\begin{array}{c}4 \cdot 0 \\
(2 \cdot 2-6 \cdot 0)\end{array}$ & $\begin{array}{c}10 \cdot 3 \\
(6 \cdot 1-13 \cdot 8)\end{array}$ & $\begin{array}{c}2 \cdot 5 \\
(0-7 \cdot 4)\end{array}$ \\
\hline 5 & Intravenous & $\begin{array}{c}67 \cdot 8 \\
(48-80)\end{array}$ & $\begin{array}{c}3.8 \\
(2 \cdot 4-5 \cdot 9)\end{array}$ & $\begin{array}{c}9 \cdot 8 \\
(8 \cdot 3-12 \cdot 4)\end{array}$ & $\begin{array}{c}23.8 \\
(19 \cdot 6-27 \cdot 2)\end{array}$ \\
\hline
\end{tabular}

Studies of the site of conversion of injected carotene

Control rats. The amount of vitamin A formed from injected carotene by intact deficient animals, or by deficient animals subjected to mock operations (anaesthesia, abdominal incision and handling of the viscera), is given in Table 5. It is apparent 
that the mock operation did not interfere with the formation of vitamin $A$ and that appreciable amounts of the vitamin were formed in this time interval.

Table 5. Vitamin $A$ and carotene in liver and kidneys and in serum of vitamin A-deficient rats injected intravenously with an aqueous dispersion of $70-100 \mu g$ carotene and killed after 4-6 $\mathrm{h}$

\begin{tabular}{|c|c|c|}
\hline \multirow[b]{2}{*}{ Exp. no. } & \multicolumn{2}{|c|}{ Serum } \\
\hline & $\begin{array}{c}\text { Vitamin A } \\
(\mu \mathrm{g} / 100 \mathrm{ml} .)\end{array}$ & $\begin{array}{c}\text { Carotene } \\
(\mu \mathrm{g} / 100 \mathrm{ml} .)\end{array}$ \\
\hline $\mathbf{I}$ & 157 & 552 \\
\hline 2 & 59 & 240 \\
\hline 3 & I 10 & 615 \\
\hline 4 & 86 & I89 \\
\hline $\begin{array}{l}5^{*} \dagger \\
6^{*}\end{array}$ & $\begin{array}{l}57 \\
97\end{array}$ & $\begin{array}{l}314 \\
654\end{array}$ \\
\hline
\end{tabular}

\begin{tabular}{|c|c|}
\hline \multicolumn{2}{|c|}{ Liver and kidneys } \\
\hline $\begin{array}{l}\text { Vitamin A } \\
\quad(\mu \mathrm{g})\end{array}$ & $\begin{array}{c}\text { Carotene } \\
(\mu \mathrm{g})\end{array}$ \\
\hline $4^{* I}$ & $38 \cdot 8$ \\
\hline $2 \cdot 7$ & $16 \cdot 2$ \\
\hline $4 \cdot 4$ & $32 \cdot 8$ \\
\hline 4.5 & $23 \cdot 3$ \\
\hline $3 \cdot 6$ & $24 \cdot 7$ \\
\hline $5 \cdot 8$ & $30 \cdot 6$ \\
\hline
\end{tabular}

* Animals subjected to mock operation before injection of carotene. $\uparrow$ Tissues of two rats pooled for analysis.

Rats with ligated bile duct. It was suggested by Mattson et al. (1947) that carotene administered parenterally might be utilized by being secreted into the intestine by way of the bile. To test this the bile ducts in four deficient rats were ligated; the animals were then injected intravenously with carotene and killed after $3 \mathrm{~h}$. The results of the analyses of serum, liver and kidneys in Table 6 prove that ligation of the bile duct did not interfere with the conversion of injected carotene. The amounts of vitamin $A$ in the serum, and in the liver and kidneys, compare favourably with what was found in control animals (Table 5). The intestines of the rats contained an average of $2.8 \mu \mathrm{g}$ carotene per rat, but no vitamin A could be detected.

Table 6. Vitamin $A$ and carotene in serum, liver and kidneys of vitamin A-deficient, bile duct-ligated rats injected intravenously with $107 \mu \mathrm{g}$ carotene in aqueous dispersion and killed after $3 h$

(Average values for pairs of rats)

\begin{tabular}{|c|c|c|c|c|c|c|}
\hline \multirow{3}{*}{$\begin{array}{c}\text { Exp. no. } \\
\text { I }\end{array}$} & \multicolumn{2}{|c|}{ Serum } & \multicolumn{2}{|c|}{ Kidneys } & \multicolumn{2}{|c|}{ Liver* } \\
\hline & $\begin{array}{l}\text { Vitamin A } \\
(\mu \mathrm{g} / 100 \mathrm{ml})(\end{array}$ & $\begin{array}{l}\text { Carotene } \\
(\mu \mathrm{g} / \mathrm{l} \text { oo ml.) }\end{array}$ & $\begin{array}{c}\text { Vitamin } A \\
(\mu \mathrm{g})\end{array}$ & $\begin{array}{c}\text { Carotene } \\
(\mu \mathrm{g})\end{array}$ & $\underset{(\mu \mathrm{g})}{\text { Vitamin } A}$ & $\begin{array}{c}\text { Carotene } \\
(\mu \mathrm{g})\end{array}$ \\
\hline & 93 & 694 & I.9 & 0.5 & $2 \cdot 1$ & I $7 \cdot 9$ \\
\hline & - & - & - & - & I.9 & $19^{\circ} \mathbf{I}$ \\
\hline 2 & 102 & 700 & $I \cdot 3$ & 0.5 & $2 \cdot 8$ & $22 \cdot 1$ \\
\hline & - & $\longrightarrow$ & - & - & $I \cdot 3$ & 14.9 \\
\hline
\end{tabular}

Enterectomized rats. When the entire small intestine was removed and the animals were injected with carotene, the formation of vitamin A (Table 7) occurred to an extent similar to that in control animals (Table 5). In general, the highest liver and kidney values were obtained from the rats permitted to live longest. The identity of the vitamin A obtained from livers and kidneys in several instances was verified by its ultraviolet-absorption maximum at 328-330 $\mathrm{m} \mu$ (in hexane) after chromatographic separation on magnesium oxide. These extracts also gave absorption maxima at $555 \mathrm{~m} \mu$ 
with activated glycerol dichlorhydrin (Sobel \& Werbin, 1945). These results prove that the rat can effectively convert carotene to vitamin $\mathrm{A}$ in tissues other than the small intestine.

Table 7. Vitamin $A$ and carotene in serum, liver and kidneys of vitamin A-deficient rats injected intravenously after enterectomy with $7^{8-100 \mu g}$ carotene in aqueous dispersion and killed after $4-7 h$

\begin{tabular}{|c|c|c|c|c|c|}
\hline \multirow[b]{2}{*}{$\begin{array}{l}\text { Exp. } \\
\text { no.* }\end{array}$} & \multirow[b]{2}{*}{$\begin{array}{l}\text { No. of } \\
\text { rats }\end{array}$} & \multicolumn{2}{|c|}{ Serum } & \multicolumn{2}{|c|}{ Liver and kidneys } \\
\hline & & $\begin{array}{c}\text { Vitamin A } \\
(\mu \mathrm{g} / 100 \mathrm{ml} .)\end{array}$ & $\begin{array}{c}\text { Carotene } \\
(\mu \mathrm{g} / \text { roo ml. })\end{array}$ & $\begin{array}{l}\text { Vitamin A } \\
(\mu \mathrm{g})\end{array}$ & $\begin{array}{c}\text { Carotene } \\
(\mu g)\end{array}$ \\
\hline I & 2 & $87 \cdot 5$ & 343 & $I \cdot 4$ & $13 \cdot 9$ \\
\hline 2 & 2 & $23 \cdot 8$ & 1057 & $1 \cdot 0$ & $19 \cdot 6$ \\
\hline 3 & 2 & $107=0$ & 820 & $3 \cdot 2$ & $23 \cdot 4$ \\
\hline 4 & 2 & $23 \cdot 7$ & 140 & $\mathrm{I} \cdot 8$ & $7 \cdot 2 \dagger$ \\
\hline 5 & 2 & $43 \cdot 2$ & 212 & $-\ddagger$ & $8 \cdot 2 \uparrow$ \\
\hline 6 & 2 & $78 \cdot 0$ & 555 & $-t$ & $22 \cdot 9$ \\
\hline 7 & I & $44^{\circ} 0$ & $45^{2}$ & $2 \cdot 0^{\circ}$ & 17.8 \\
\hline 8 & I & $-\ddagger$ & $-\ddagger$ & $3 \cdot 1$ & $22 \cdot 0$ \\
\hline 9 & I & $-i$ & $-i$ & $5 \cdot 1$ & $-\ddagger$ \\
\hline
\end{tabular}

* When two rats were used, the tissues were pooled for analysis.

$\dagger$ Only $3^{8} \mu \mathrm{g}$ carotene were injected.

$\ddagger$ Where no values are given, the analyses were either not made or were unsatisfactory.

Nephrectomized rats. In several experiments from which the livers and kidneys of deficient rats injected with carotene were analysed separately, it was found that about equal amounts of vitamin $\mathrm{A}$ were in these tissues and that occasionally more was present in the kidneys than in the liver. It is known that when the total storage is low, the vitamin A in the kidneys may exceed that in the liver (Johnson \& Baumann, 1947). This suggests that some conversion of carotene may occur in the kidneys. To test this, deficient rats were bilaterally nephrectomized, injected intravenously with carotene and killed $4^{-6} \mathrm{~h}$ later. The vitamin $\mathrm{A}$ in the serums and livers (Table 8 ) was similar to that found in intact rats given similar amounts of carotene (Table 5). Thus, the kidneys cannot be considered an important site of vitamin A production from carotene.

Table 8. Vitamin $A$ and carotene in serum and liver of vitamin $A$-deficient rats injected intravenously after nephrectomy with 100 $\mu g$ carotene in aqueous dispersion and killed after 4-6 $h$

\begin{tabular}{|c|c|c|c|c|}
\hline \multirow[b]{2}{*}{$\begin{array}{l}\text { Exp. } \\
\text { no. }\end{array}$} & \multicolumn{2}{|c|}{ Serum } & \multicolumn{2}{|c|}{ Liver } \\
\hline & $\begin{array}{c}\text { Vitamin A } \\
\text { ( } \mu \mathrm{g} / \text { roo ml. })\end{array}$ & $\begin{array}{c}\text { Carotene } \\
(\mu \mathrm{g} / \mathrm{roo} \mathrm{ml.)}\end{array}$ & $\begin{array}{l}\text { Vitamin } A \\
(\mu \mathrm{g})\end{array}$ & $\begin{array}{c}\text { Carotene } \\
(\mu g)\end{array}$ \\
\hline I & I6I & 567 & $2 \cdot 3$ & 247 \\
\hline 2 & 75 & 366 & $2 \cdot 0$ & $28 \cdot I$ \\
\hline 3 & II3 & 207 & $I \cdot 5$ & $34 \cdot 2$ \\
\hline 4 & I I 3 & 298 & $I \cdot 5$ & 25.5 \\
\hline $5^{*}$ & 72 & 466 & $x \cdot 6$ & 25.8 \\
\hline
\end{tabular}

Hepatectomized rats. The results of injecting carotene into animals in which $60-75 \%$ of the liver had been removed are presented in Table 9. When compared 
with the vitamin $A$ found in the preceding experiments, it can be seen that the amounts are similar to those formed by intact, nephrectomized or enterectomized animals. The variations in survival time and in the dosage of carotene in the different experiments, as well as the individual variation among rats, do not make it possible to state that the removal of any one organ affects the conversion of carotene to vitamin A more profoundly than does removal of any other. Even when more than one-half of the liver is removed, the formation of vitamin A from circulating carotene is clearly not appreciably impaired.

Table 9. Vitamin $A$ and carotene in serum, liver and kidneys of vitamin A-deficient, hepatectomized ( $60-75 \%$ of liver removed) rats injected intravenously with $75-100 \mu g$ carotene in aqueous dispersion and killed after $4^{-8} h$

$\begin{array}{ccccc}\begin{array}{c}\text { Exp. } \\ \text { no. }\end{array} & \begin{array}{c}\text { Vitamin A } \\ (\mu \mathrm{g} / \text { roo ml. })\end{array} & \begin{array}{c}\text { Carotene } \\ (\mu \mathrm{g} / \text { roo ml. })\end{array} & \overbrace{\begin{array}{c}\text { Vitamin A } \\ (\mu \mathrm{g})\end{array}}^{\text {Serum }} & \begin{array}{c}\text { Carotene } \\ (\mu \mathrm{g})\end{array} \\ \mathbf{1} & 76 \cdot 0 & 965 & 4 \cdot 6 & 30 \cdot 5 \\ 2 & 41 \cdot 0 & 725 & 2 \cdot 2 & 18 \cdot 9 \\ 3 & 35 \cdot 2 & 615 & 1 \cdot 9 & 17 \cdot 9 \\ 4^{*} & 48 \cdot 0 & 629 & 1 \cdot 2 & 13 \cdot 8 \\ 5 & 19 \cdot 9 & 366 & 2 \cdot 9 & 11 \cdot 4 \\ & * & & \end{array}$

DISCUSSION

The high levels of vitamin A that appear in the blood shortly after the intravenous injection of solubilized carotene point to efficient conversion. Although the serum content of vitamin A decreases quickly after the administration of a single dose of carotene, a high blood level of the vitamin persists for a day, and probably longer, after repeated carotene injections, and the amounts of vitamin $A$ found in the liver and kidneys, as well as in the blood, are similar to those present after the same repeated dosage of carotene orally.

The low serum-vitamin A concentration of 6-10 $\mu \mathrm{g} / 100 \mathrm{ml}$, which persists for 7-15 days, or longer, after a single intravenous injection of carotene, would appear to be maintained as a result of the conversion of carotene deposited in the liver. This view is supported by the observation that the carotene in the liver slowly disappears and that when the animal eventually died from vitamin A deficiency, the liver store of carotene was essentially nil.

The inability to account for one-third to one-half of a dose of carotene either as carotene or as vitamin $\mathrm{A}, 4^{-24} \mathrm{~h}$ after its injection, and the finding that no carotene was excreted in the urine or faeces, indicate a rapid destruction of the pigment to noncarotenoid-like substances. One wonders if the formation of vitamin $A$ from carotene is the result of a specific oxidation, or if in the breakdown of carotene vitamin $A$ is just one of many products.

From the observation that the conversion of circulating carotene occurred essentially undiminished when the small intestine was removed, it is apparent that tissues other than the intestine possess the ability to form vitamin A from carotene. The kidneys 
were not involved to any significant extent. Since the liver is able to utilize stored carotene, it would seem probable that this organ is primarily responsible for the formation of vitamin A from injected carotene, although the provitamin may be transported elsewhere for the conversion.

From the experiments in which over one-half of the liver was removed before carotene injection, it cannot be stated that a direct relationship between the amount of tissue present and the amount of vitamin $A$ formed has been demonstrated. If the liver is the site of conversion, the experiments show that appreciable formation of vitamin A can occur even when the amount of liver tissue is considerably reduced. The possibility must be considered that perhaps many tissues have the ability to convert carotene. However, when the provitamin is administered orally the intestine is the predominant site of conversion, since essentially no carotene normally circulates in the rat. From the observation that small doses of carotene protected with tocopherol were more effective orally than when injected, both in curing vitamin A-deficient rats and in preventing a deficiency in normal rats, it may be concluded that the intestinal utilization is the more efficient.

\section{SUMMARY}

I. Aqueous dispersions of carotene produced a better growth response in vitamin Adepleted rats when injected intravenously than when given orally. If $\alpha$-tocopherol was incorporated into the supplement, however, the oral route was slightly more effective.

2. In moderately or severely deficient rats, low doses of carotene with or without tocopherol were considerably less effective intravenously than orally, but a larger dose with tocopherol was utilized about equally by the two routes of administration.

3. Four hours after injecting carotene intravenously, about $67 \%$ of the dose could be recovered from the body. Of this, the bulk was deposited in the liver and carcass, with only $2 \mu \mathrm{g}$, or less, present in the small intestine, kidneys, lungs, heart and spleen.

4. Intravenously administered carotene was rapidly converted into vitamin $A$, as shown by the appearance of the vitamin in the blood, liver and kidneys. When repeated doses of carotene were given orally or intravenously to deficient rats, the resulting amounts of vitamin $A$ in the serum, liver and kidneys of the two groups were similar.

5. From 35 to $39 \%$ of a dose of injected carotene was taken up by the liver in I2-18 h. Such stored carotene was slowly metabolized by the animal and had disappeared when the animal eventually died from vitamin A deficiency.

6. The formation of vitamin A from injected carotene occurred essentially unimpaired after ligation of the bile duct, removal of small intestine or kidneys or removal of $60-75 \%$ of the liver.

The authors wish to thank Dr F. P. Griffiths of the Western Regional Research Laboratory and Dr Henry F. Espoy of Barnett Laboratories for generous supplies of crystalline carotene. Our gratitude is expressed to Dr J. C. Finerty, Department of Anatomy, and to Dr C. E. Hall, Department of Physiology, for demonstrating various surgical procedures. This study was supported by a contract between the Office of Naval Research, Department of the Navy, and the University of Texas. 
REFERENCES

Bessey, O. A., Lowry, O. H., Brock, M. J. \& Lopez, J. A. (1946). 7. biol. Chem. 166, 177.

Bieri, J. G. (1951). F. Nutr. 44, 327.

Bieri, J. G. \& Sandman, R. P. (1951). Proc. Soc. exp. Biol., N.Y., 77, 6 I 7.

Bieri, J. G. \& Schultze, M. O. (195 I a). Arch. Biochem. Biophys. 34, 273.

Bieri, J. G. \& Schultze, M. O. (1951 b). Arch. Biochem. Biophys. 34, 280.

Drummond, J. C., Gilding, H. P. \& Macwalter, R. J. (1934). Y. Physiol. 82, 75.

Drummond, J. C. \& Macwalter, R. J. (1935). F. Physiol. 83, 236.

Eaton, H. D., Matterson, L. D., Decker, L., Helmboldt, C. F. \& Jungherr, E. L. (195I). F. Dairy Sci. 34, 1073 .

Farris, E. J. \& Griffith, J. Q. Jr. (1949). The Rat in Laboratory Investigation, 2nd ed. Philadelphia: J. B. Lippincott Co.

Glover, J., Goodwin, T. W. \& Morton, R. A. (1947). Biochem. F. 4r, xlv.

Harris, P. L., Kaley, M. W. \& Hickman, K. C. D. (1944). F. biol. Chem. 152, 313.

Johnson, R. M. \& Baumann, C. A. (1947). Arch. Biochem. 14, 361.

Kowalewski, K., Henrotin, E. \& van Geertruyden, J. (195 I). Acta gastro-enterol. belg. 14, 607. Quoted in Nutr. Abstr. Rev. (1952), 21, 599.

Lease, J. G., Lease, E. J., Steenbock, H. \& Baumann, C. A. (1942). F. Lab. clin. Med. 27, 502.

Mattson, F. H., Mehl, J. W. \& Deuel, H. J. Jr. (1947). Arch. Biochem. 15, 65.

Sexton, E. L., Mehl, J. W. \& Deuel, H. J. Jr. (1946). F. Nutr. 31, 299.

Sobel, A. E. \& Werbin, H. (1945). F. biol. Chem. 159, 681.

Thompson, S. Y., Ganguly, J. \& Kon, S. K. (1947). Brit. F. Nutr. I, v.

Tomarelli, R. M., Charney, J. \& Bernhart, F. W. (1946). Proc. Soc. exp. Biol., N. Y., 63, 108.

\title{
Nutritional Deficiency and Wallerian Degeneration in the Rat
}

\section{Effect of Protein Depletion on the Goncentration of Nucleic Acid and Phospholipid in Intact and Sectioned Nerves}

\author{
By W. A. MANNELL AND R. J. ROSSITER \\ Department of Biochemistry, University of Western Ontario, London, Canada
}

(Received 6 fuly 1953)

If a peripheral nerve is cut, that portion of the nerve distal to the point of section undergoes a series of changes characteristic of Wallerian degeneration. Logan, Mannell \& Rossiter ( $195^{2} a$ ) showed that in the distal segment of the sciatic nerve of the cat degenerating after nerve section there is an increase in the concentration of nucleic acid. This change, which is probably related to the cellular proliferation known to occur in Wallerian degeneration, involves both pentosenucleic acid (PNA) and deoxypentosenucleic acid (DNA), but the change is disproportionate, so that there is an increase in the PNA: DNA ratio. Johnson, McNabb \& Rossiter (1949) showed that there is also a later decrease in the concentration of myelin lipid, related to the destruction of the myelin sheath. Mannell (1952) reported similar changes in the sciatic nerve of the rat, although for this species all the processes are considerably speeded up. By measuring the respective changes in the concentrations of nucleic acid and phospholipid, a rough quantitative estimate may be obtained both of the total number of cells and of the amount of myelin material present in a given portion of the nerve. 